\title{
TRADUÇÃO E INTERPRETAÇÃO DAS LÍNGUAS DE SINAIS
}

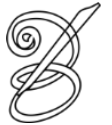 \\ José Ednilson Gomes de SOUZA-JÚNIOR ${ }^{\mathrm{i}}$ \\ Mestre em Linguística pela Universidade de Brasília (UnB) \\ Professor do Bacharelado em Letras/LIBRAS \\ Universidade Federal de Santa Catarina (UFSC) \\ Florianópolis, Santa Catarina, Brasil \\ jose.souza.junior@ufsc.br
}

A ampliação das pesquisas sobre tradução e interpretação das Línguas de Sinais vem crescendo a cada ano no Brasil. Na próxima década, poderá ganhar mais força como consequência da criação dos cursos superiores de formação específica em sete universidades federais brasileiras: Universidade Federal de Santa Catarina - UFSC, Universidade Federal de São Carlos - UFSCar, Universidade Federal do Rio Grande do Sul - UFRGS, Universidade Federal de Roraima - UFRR, Universidade Federal do Espírito Santo - UFES, Universidade Federal de Goiás - UFG e Universidade Federal do Rio de Janeiro - UFRJ.

Para marcar este momento atual, a Revista Belas Infiéis dedica neste número um dossiê especial às investigações sobre a "Tradução e Interpretação das Línguas de Sinais". Apresentamos, pois, aqui, 10 artigos voltados ao tema que abordam os contextos nacionais e internacionais.

No primeiro artigo deste número intitulado As mediações linguísticas do intérprete de Língua de Sinais, Dayse Garcia Miranda, da Universidade Federal de Ouro Preto, analisa as características de uma sala de aula inclusiva, bilíngue, de escola regular com a presença de intérprete educacional. A autora nos evidencia que a atuação do Intérprete de Língua de Sinais precisa considerar aspectos de modalidade e também extralinguísticos em seu trabalho.

Na sequência, no artigo Unexpected moment - possibilidades de tradução Diego Barbosa, Leomaris Aires e Maitê Maus da Silva nos apresentam um estudo sobre possibilidades de tradução à luz das estratégias funcionalistas. Nessa pesquisa, os autores consideraram as questões culturais relevantes na elaboração dos textos meta, mas ponderaram a flexibilidade existente nos Sinais Internacionais - língua base das traduções.

Sob o título $O$ deslocamento das legitimidades dos Tradutores/Intérpretes de Libras e Português e os imaginários, Luiz Cláudio da Silva Souza, da Universidade Federal de Goiás, 
nos apresenta um artigo provocativo sobre a constituição e fragmentação do ethos dos intérpretes de língua de sinais. Ele considera questões históricas que impactam as relações político-institucionais e a própria atuação profissional para sustentar sua hipótese.

Em uma produtiva intersecção dos estudos linguísticos e dos estudos da tradução, Maria Cristina Pires Pereira apresenta o artigo A Tomada de Posição (stance-taking) na Interpretação Interlíngue de Língua de Sinais. Ela considera que as escolhas interpretativas, em termos de referenciação podem refletir uma menor interferência do mediador na enunciação.

Problematizando a tradução literária para a Língua de Sinais, Neiva de Aquino Albres, da Universidade Federal de Santa Catarina, discute em seu artigo A construção de sinais-nome para os personagens na tradução de literatura infanto-juvenil para Libras o processo de elaboração de nomes próprios na língua de sinais a partir de traduções de textos infanto-juvenis. A partir de diferentes obras, ela analisa e categoriza os nomes próprios identificados e conclui que a imagem ilustrativa dos personagens constitui um papel fundamental na criação de seus respectivos nomes em língua de sinais.

Saionara Figueiredo Santos, do Instituto Federal de Santa Catarina e doutoranda da Universidade Federal de Santa Catarina, nos apresenta a Tradução comentada do poema "debussy", de manuel bandeira, para a Língua Brasileira de Sinais Tal estudo tem por finalidade evidenciar o processo tradutório e a compreensão das escolhas por parte do tradutor, que, segundo a autora, é influenciado pela sombra da fidelidade, da equivalência e da invisibilidade do tradutor.

No âmbito da interpretação comunitária, Silvana Aguiar dos Santos, da Universidade Federal de Santa Catarina, expõe sua pesquisa sobre algumas dificuldades enfrentadas por Intérpretes de Língua de Sinais que atuam no âmbito jurídico no artigo Questões emergentes sobre a interpretação de Libras-Português na esfera jurídica. A autora coteja a realidade internacional com o que ela observou em sua pesquisa qualitativa local e conclui apontando a emergência de formação específica para a atuação no meio jurídico.

Susana Barbosa e seus colegas trazem até nós o conhecimento sobre a situação dos intérpretes de língua de sinais em Portugal no artigo $O$ intérprete de língua gestual portuguesa - conhecer a profissão. Eles analisam vários aspectos do cotidiano dos Intérpretes: a formação, as questões profissionais, as parcerias do intérprete no contex to educativo, a interpretação para voz e também a saúde ocupacional.

Em seguida, Vanessa Regina de Oliveira Martins, da Universidade Federal de São Carlos, enfatiza em seu artigo Tradutor e intérprete de língua de sinais educacional a 
necessidade da ação pedagógica do tradutor e intérprete de língua de sinais educacional em sala de aulas inclusivas. Estes atuam na mediação entre sujeitos, mas também entre conhecimentos. A autora conclui indicando a formação como uma peça-chave para a melhor atuação dos intérpretes educacionais.

Por fim, e complementando a pesquisa anterior, o artigo $O$ intérprete de Libras educacional: o processo dialógico de mediação na pós-graduação de Vânia de Aquino Albres Santiago e Cristina Broglia Feitosa de Lacerda, também da Universidade Federal de São Carlos, apresenta um estudo etnográfico sobre a atuação de intérpretes educacionais no nível superior. As autoras tratam das relações entre os sujeitos, das relações dialógicas na interação entre eles e da construção de sentidos para ambos. As autoras concluem que se faz necessário potencializar a formação específica de intérpretes educacionais.

Assim, finalizamos essa edição do dossiê especial consolidando o espaço das Língua de Sinais nas pesquisas, estudos e publicações no campo dos Estudos da Tradução e aproveitamos a oportunidade para agradecemos aos autores, aos pareceristas e à equipe editorial da Revista Belas Infiéis pela colaboração.

Ficamos muito felizes em organizar e apresentar ao público leitor este dossiê especial da Revista Belas Infiéis que dedicamos à memória de Ernando Chaves Pinheiro, presidente da Federação Brasileira das Associações de Tradutores e Intérpretes de Língua Brasileira de Sinais e professor da Universidade Federal do Ceará. Ernando deixou precocemente este mundo, mas reconhecemos e lembramos aqui sua contribuição para a formação educacional e política dos intérpretes de Libras de sua região e do país.

\footnotetext{
i José Ednilson Gomes de Souza-Júnior - Tradutor e Intérprete. Mestre em Linguística pela Universidade de Brasília/UnB. É professor do Departamento de Libras (DALi) do Centro de Comunicação e Expressão (CCE) da Universidade Federal de Santa Catarina (UFSC). Atua como Vice-presidente da World Association of Sign Language Interpreters (WASLI). É também vice-líder do Grupo de Pesquisa Didática e Ensino de Tradutores e Interpretes de Línguas de Sinais - DETILS, onde coordena a linha de pesquisa "Tradução Especializada, Terminologia e Ensino" e é membro do INTERTRADS - Grupo de Pesquisas em Interpretação e Tradução de Línguas de Sinais onde coordena a linha de pesquisa "Tradução e Interpretação em contextos midiáticos". Disponível em: http://lattes.cnpq.br/0519894675464006 e http://souzajunior.paginas.ufsc.br. Acesso: junho de 2016.
} 